\title{
Rancang Bangun Aplikasi Piano Virtual Menggunakan Teknologi Augmented reality dan Vuforia SDK
}

\author{
Rahma Fida Fadhilah, Nanik Suciati, dan Wijayanti Nurul Khotimah \\ Jurusan Teknik Informatika, Fakultas Teknologi Informasi, Institut Teknologi Sepuluh Nopember (ITS) \\ Jl. Arief Rahman Hakim, Surabaya 60111 Indonesia \\ e-mail:nanik@if.its.ac.id,wijayanti@if.its.ac.id,rahma.fida@gmail.com
}

\begin{abstract}
Abstrak-Piano yang diketahui berbentuk besar, tidak portabel dan relatif mahal sehingga banyak masyarakat yang memanfaatkan kemajuan teknologi untuk belajar piano melalui teknologi komputer. Telah banyak aplikasi bermain piano yang ada, namun metode yang digunakan kurang menarik. Oleh karena itu, perlu dibuat sebuah aplikasi yang dapat menjadikan piano lebih menarik untuk dimainkan. Salah satu teknologi yang sedang berkembang saat ini adalah teknologi Augmented reality (AR). AR mampu memberikan pengalaman yang interaktif dengan menampilkan objek 3 dimensi sehingga terlihat nyata kepada pengguna. Untuk mengembangkan tampilan AR, digunakan Library Vuforia SDK. Pengguna juga dapat menyentuh langsung tombol virtual atau Virtual button yang merupakan fitur bawaan Library Vuforia SDK. Hasil pengujian aplikasi menunjukkan bahwa aplikasi dapat menampilkan objek piano dengan tampilan AR dan pengguna dapat menyentuh tombol virtual. Maka dari itu, aplikasi yang dibangun berhasil memberikan pengalaman baru kepada pengguna dari segi tampilan dan permainan.
\end{abstract}

Kata Kunci-Augmented reality, Perangkat Mobile, Piano Virtual, Virtual button dan Vuforia SDK

\section{PENDAHULUAN}

$\mathrm{M}$ USIK adalah bunyi yang mengandung unsur-unsur tertentu yang dihasilkan oleh alat musik atau vokal ataupun keduanya. Musik dapat dihasilkan dari alat musik yang salah satunya adalah piano. Piano adalah alat musik yang menggunakan jari untuk memainkan alatnya dengan cara menekan tuts piano. Piano tidak portabel dan sering mahal sehingga banyak masyarakat yang memanfaatkan kemajuan teknologi untuk belajar musik mulai dari drum, gitar, bass, piano ataupun alat musik lainnya melalui teknologi komputer.

Sementara itu, dalam bidang komputer terdapat teknologi yang disebut Augmented reality (AR). Pada dasarnya AR memiliki kelebihan yaitu mampu memberikan pengalaman yang interaktif kepada pengguna. Ini berarti tidak menutup kemungkinan bahwa teknologi ini dapat dijadikan alat untuk bermain musik yang lebih menyenangkan. Dari metode yang membosankan dan dianggap sulit itu menjadikan antusiasme masyarakat menurun untuk bermain musik di piano. Dengan menggunakan teknologi AR, metode yang membosankan itu dapat diminimalisasi sehingga dapat menjadi metode bermain alat musik piano yang lebih menarik karena AR mampu memberikan pengalaman yang interaktif kepada pengguna.

Dalam AR sendiri telah banyak pengaplikasian Virtual button yang merupakan fitur bawaan Library Vuforia SDK. Virtual button sendiri adalah tombol bersifat visual yang memungkinkan penggunanya untuk menyentuh tombol tersebut sehingga dapat menghasilkan berbagai macam output, seperti animasi, suara dan lain-lain. Virtual button akan muncul saat animasi AR telah muncul sehingga memungkinkan pengguna mendapatkan sensasi dan pengalaman untuk terlibat sendiri dalam teknologi AR tersebut sehingga sangat interaktif untuk menjadi metode bermain alat musik piano [1].

Maka dari itu, penulis membuat aplikasi alat musik piano virtual Menggunakan Teknologi AR dan Vuforia SDK. Dengan adanya aplikasi ini, diharapkan dapat menjadi metode dalam bermain piano yang mampu memberikan pengalaman luar biasa dan tidak membosankan sekaligus menjadi media edukasi untuk pengguna mengenai alat musik piano.

\section{TINJAUAN PUSTAKA}

\section{A. Piano}

Piano adalah alat musik yang dimainkan dengan jari-jemari tangan dengan menggunakan keyboard. Untuk membuat rangkaian nada harmonis pada piano dapat menggunakan chord. Chord atau kunci nada adalah rangkaian dua nada atau lebih secara bersama - sama sehingga menimbulkan kesan indah. Permainan chord digunakan untuk mengiringi jalannya suatu lagu [2].

Pada piano terdapat kunci not yang merupakan deretan tuts yang jika ditekan, maka akan mengeluarkan suara berdasarkan kunci note yang ada. Dimulai dari kunci paling kecil yang terletak di sebelah kiri berurutan hingga kunci paling besar di sebelah kanan. Tuts berwarna putih mengandung kunci $\mathrm{C}$ Mayor, yaitu: C,D,E,F,G,A,B. sedangkan tuts berwarna hitam mengandung kunci selain C Mayor, yaitu C\#, D\#. F\#, G\#, A\# [3].

\section{B. Augmented reality}

Augmented reality (AR) adalah teknologi yang menggabungkan objek dua atau tiga dimensi yang digambarkan dan diproyeksikan bersamaan dengan lengkungan nyata secara real time. Pada dasarnya objek animasi tersebut ada atau ditambahkan kedalam kehidupan nyata dengan alat bantu penglihatan atau layar. AR memanfaatkan fitur gyroscope dan accelerometer dalam memproyeksikan objek sehingga dapat dilihat dari sudut manapun, tidak terganggu oleh lingkungan nyata, dan bahkan 
dapat beradaptasi dengannya [4].

\section{Vuforia $S D K$}

Vuforia adalah Software Development Kit (SDK) untuk perangkat mobile dalam pembuatan aplikasi Augmented reality. Vuforia SDK membantu mengombinasikan kamera perangkat mobile sebagai perangkat masukan, sebagai mata elektronik yang mengenali penanda tertentu sehingga dapat muncul objek animasi di kehidupan nyata [5].

Vuforia menggunakan teknologi computer vision yang mengenali dan menelusuri gambar planar yang digunakan sebagai gambar target dan objek 3D seperti kubus, dalam satuan waktu yang nyata. Kemampuan pengenalan gambar ini memungkinkan pengembang untuk menentukan posisi dan arah objek virtual, seperti model 3D dan media lain, yang berkaitan dengan gambar dunia nyata ketika dilihat melalui kamera perangkat mobile. Objek virtual tersebut akan menelusuri posisi dan orientasi dari gambar tersebut, sehingga dari perspektif pengguna, objek berkorespondensi dengan perspektif gambar target, sehingga objek virtual tersebut akan tampak terlihat seperti bagian dari dunia nyata [6]. Adapun arsitektur sistem dari Vuforia SDK adalah seperti Gambar 1.

\begin{tabular}{|c|c|c|c|c|c|c|}
\hline $\begin{array}{l}\text { Virtual } \\
\text { Button }\end{array}$ & $\begin{array}{l}\text { Multi } \\
\text { Target }\end{array}$ & $\begin{array}{l}\text { Image } \\
\text { Target }\end{array}$ & $\begin{array}{l}\text { Word } \\
\text { Target }\end{array}$ & $\begin{array}{l}\text { Cylinder } \\
\text { Target }\end{array}$ & $\begin{array}{l}\text { Frame } \\
\text { Marker }\end{array}$ & \multirow[t]{2}{*}{$\begin{array}{l}\text { Developer } \\
\text { Application }\end{array}$} \\
\hline \multicolumn{6}{|c|}{ Tracker } & \\
\hline \multicolumn{6}{|c|}{ Camera } & Rendering \\
\hline \multicolumn{7}{|c|}{ os } \\
\hline
\end{tabular}

Gambar 1. Arsitektur Sistem Vuforia SDK

\section{Marker}

Dalam Vuforia SDK, marker atau penanda adalah sesuatu yang dapat dikenali oleh masukan perangkat mobile dalam pengembangan Augmented reality. Penanda akan berbedabeda yang merujuk pada objek yang dihasilkan beserta datanya. Penanda dapat dicetak dengan ukuran apapun dan semakin berbeda corak yang dipakai maka akan bagus pula kemampuan tracking sistemnya. Objek akan muncul diatas penanda yang telah dicetak dan dapat berinteraksi sesuai dengan hasil pengembangannya [7].

\section{E. Virtual button}

Virtual button adalah sebuah area persegi di dalam area penanda, yang digunakan untuk men-trigger sebuah event tertentu dengan menyentuhnya. Virtual button dapat digunakan untuk mengimplementasikan event seperti OnButtonPress atau untuk mendeteksi apakah area tertentu dari image target ditutupi sebuah objek tertentu. Event pada virtual button hanya dapat dieksekusi ketika tampilan dari kamera dan kamera tersebut stabil. Artinya, jika terjadi perpindahan kamera secara cepat, maka virtual button akan didisable.

Virtual button didefinisikan dalam konfigurasi dataset .unitypackage yang menjadi property dari image target (penanda). Dengan menggunakan virtual button interaksi antara objek 3 dimensi dengan pengguna dapat dilakukan.
Karena virtual button merupakan property dari image target, maka virtual button hanya dapat berpindah sepanjang gambar penanda atau image target. Virtual button berupa tombol virtual yang dapat ikut berpindah bersama objek 3 dimensi yang menjadi parent dari virtual button tersebut [8].

\section{ANALISIS DAN PERANCANGAN}

\section{A. Analisis Perangkat Lunak}

Aplikasi piano virtual menggunakan penanda berupa gambar sebagai pendeteksi objek 3D yang akan ditampilkan. Interaksi antara pemain dengan objek 3D dilakukan dengan menggunakan inputan berupa objek yang menyentuh area penanda dalam aplikasi ini berupa tombol virtual atau virtual button, di mana saat di-render, virtual button akan ditandai dengan warna tertentu di kamera. Sehingga saat disentuh, objek memiliki perilaku yang berbeda. Pengguna diberi dua pilihan untuk bermain piano secara bebas atau bermain lagu yang telah disediakan pada piano untuk mengejar skor tertinggi yang mana terdapat level normal dan hard dengan menggunakan tangan untuk menyentuh virtual button di gambar penanda. Semakin banyak tuts yang berhasil ditekan, maka semakin meningkat skor yang diperoleh pengguna. Dalam fitur ini, terdapat waktu yang telah ditentukan untuk mengumpulkan skor sebanyak-banyaknya.

Kebutuhan utama dalam aplikasi ini antara lain :

1. Pengguna dapat memilih jenis permainan yang diinginkan

2. Pengguna dapat memilih jenis suara musik pada piano

3. Pengguna dapat memilih lagu untuk dimainkan

4. Pengguna dapat memilih tingkatan level pada permainan

5. Pengguna dapat memainkan piano virtual dengan adanya visualisasi Augmented reality Piano Virtual pada kamera handphone.

Adapun gambaran arsitektur secara umum aplikasi dapat dilihat pada Gambar 2.

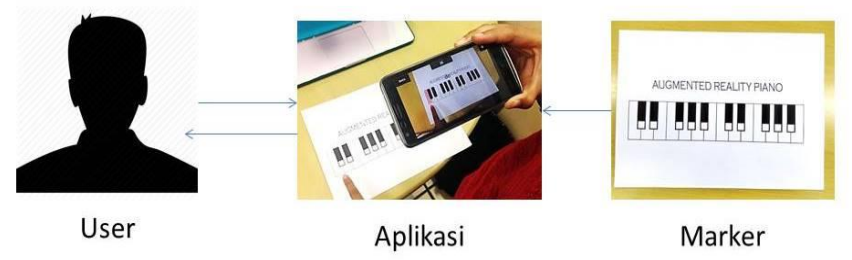

Gambar 2. Rancangan Sederhana Arsitektur Aplikasi

\section{B. Perancangan Perangkat Lunak}

Pada perancangan perangkat lunak menjelaskan perancangan proses beserta alurnya. Pada aplikasi memiliki rancangan proses yang dilakukan untuk mendukung fungsionalitas yang sudah dirancang pada aplikasi dimulai dari proses pendeteksian penanda, penanda yang telah terdeteksi, aplikasi menampilkan objek tiga dimensi, hingga pemain dapat mulai bermain. Penjelasan proses perancangan pada aplikasi dijelaskan pada berikut ini.

1. Proses Deteksi Gambar Penanda

Gambar yang akan dijadikan penanda, terlebih dahulu harus diunggah ke dalam situs Target Manager Vuforia, yaitu sebuah situs yang memiliki sistem pendeteksian kelayakan kualitas dari suatu gambar untuk dapat dijadikan penanda. Gambar 
yang telah memiliki rating yang cukup baik dapat dijadikan sebagai penanda, yaitu dengan cara mengunduh file .unitypackage yang berisi identitas penanda dan ukuran ketajaman penanda yang akan digunakan. File yang telah diunduh di-import dalam kakas bantu yang digunakan untuk membangun aplikasi ini.

Proses gambar penanda ini dimulai dengan pengecekan ketersediaan gambar penanda. Sistem akan mencari gambar penanda melalui camera device yang digunakan. Gambar penanda dicari dan disesuaikan dengan gambar penanda yang telah tersimpan di sistem. Jika gambar penanda belum ditemukan, maka sistem akan terus mencari. Dan jika telah ditemukan gambar penanda, maka sistem akan menampilkan objek 3 dimensi ke lingkungan pengguna. Sistem Vuforia SDK akan mengenali penanda dan mulai membangun objek 3 dimensi dengan alur proses yang digambarkan pada Gambar 3 .

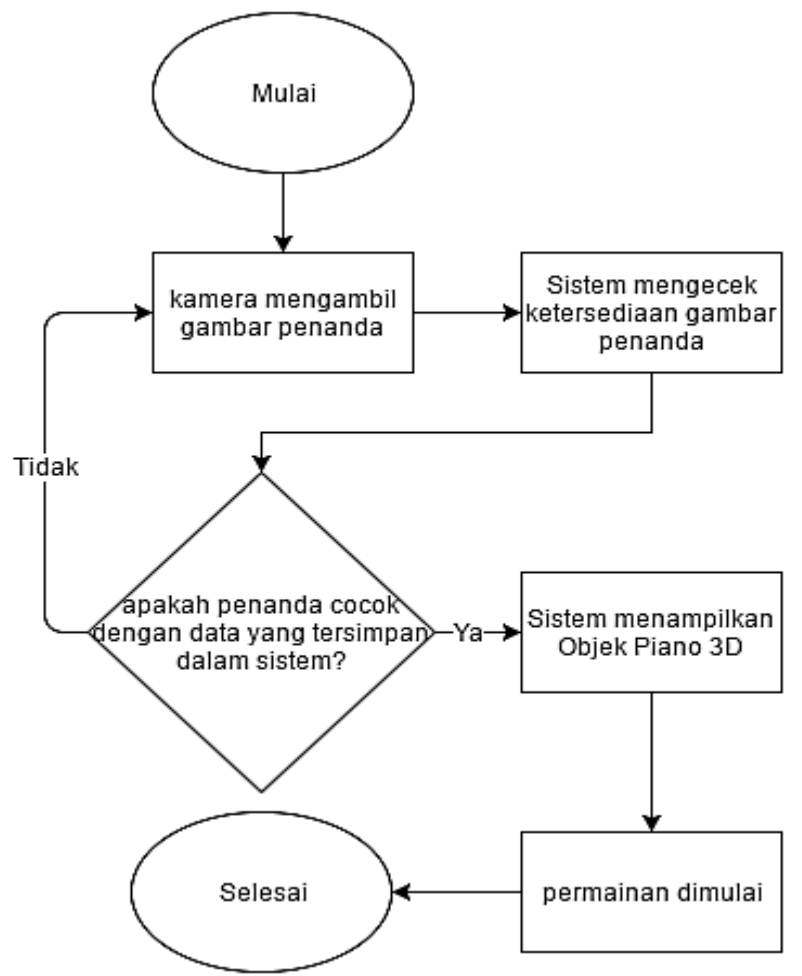

Gambar 3. Alur Proses Mendeteksi Gambar Penanda

\section{Proses Permainan}

Proses permainan dilakukan dengan melakukan pengecekan terhadap kondisi start terlebih dahulu. Saat aplikasi berada pada kondisi start, maka akan ditampilkan pilihan jenis permainan. Pengguna memilih jenis permainan yang diinginkan. Terdapat dua jenis, yaitu freeplay dan challenge. Diagram Alur proses permainan digambarkan pada Gambar 4.

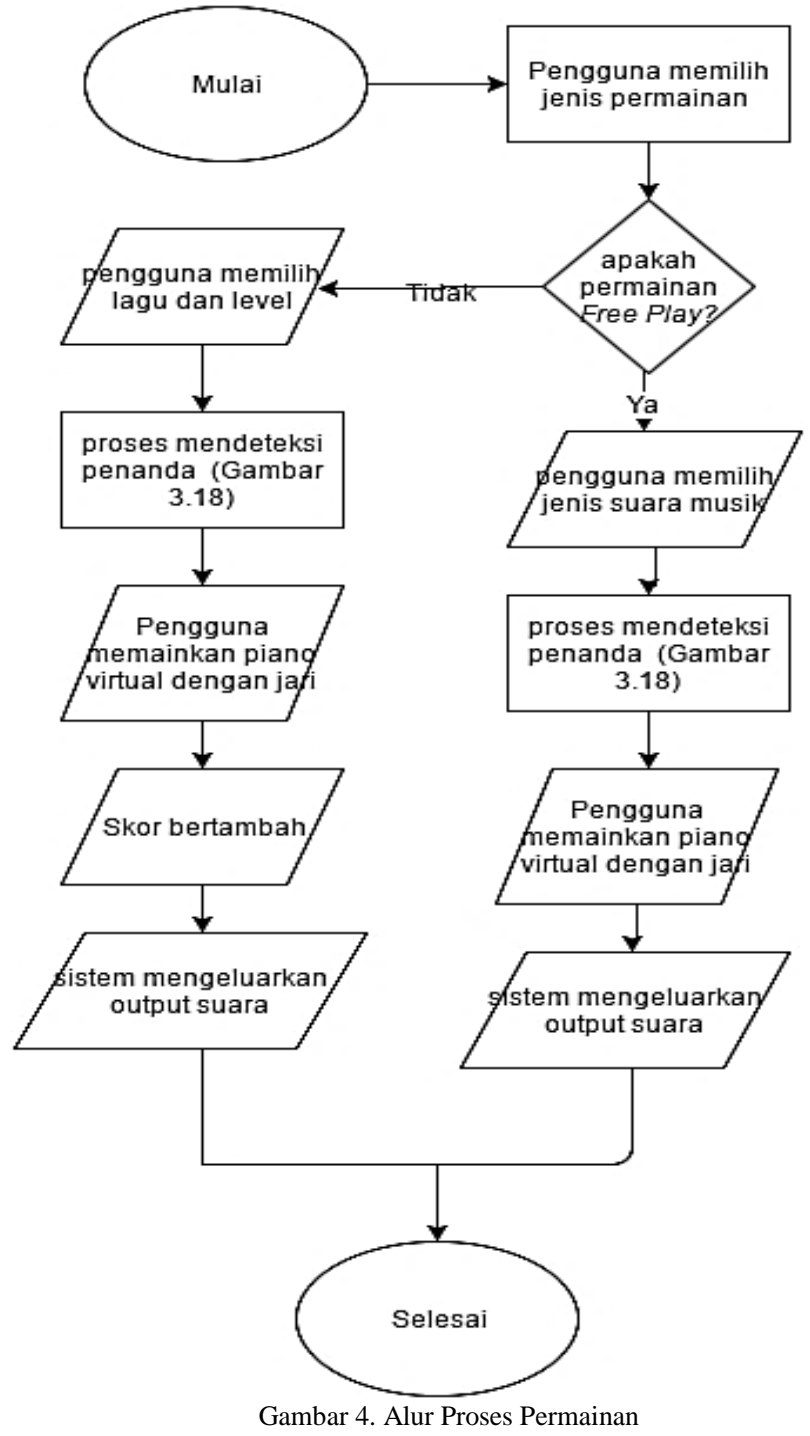

Pada jenis permainan Free Play, pada awalnya pengguna memilih jenis suara musik yang diinginkan. Kemudian pengguna dapat memainkan piano virtual secara bebas tanpa ada waktu dan score sesuai dengan jenis suara musik yang dipilih.

Pada jenis permainan Challenge, pengguna diberikan tantangan memainkan piano virtual dengan lagu yang telah dipilih dan terdapat waktu yang telah ditentukan dimana pada akhir permainan terdapat skor yang telah berhasil dicapai pengguna. Terdapat dua level pada permainan, yaitu Normal dan Hard. Pada level Normal, pengguna bermain piano virtual dengan waktu yang telah ditentukan dan pengguna harus menekan tombol yang berwarna merah untuk mendapatkan skor. Tombol tidak akan berpindah jika pengguna tidak menekan tombol tersebut. Sedangkan pada level Hard, pengguna juga bermain piano dengan waktu yang telah ditentukan dan harus menekan tombol yang berwarna merah secepat-cepatnya. Jika tombol tidak tertekan dalam waktu tertentu, tombol berwarna merah secara otomatis akan berpindah. Diakhir permainan, skor akan muncul.

Setelah memilih jenis permainan yang diinginkan. Pengguna memilih menu-menu yang telah disediakan aplikasi sesuai jenis permainan yang dipilih. Kemudian dilanjutkan 
dengan proses interaksi pengguna dengan objek 3 dimensi diawali dengan pendeteksian posisi jari pemain pada daerah di sepanjang penanda. Selama posisi jari tidak berada dalam area virtual button, maka tidak akan ada kejadian (event) yang akan dieksekusi. Interaksi hanya dapat terjadi ketika jari pemain berada di area atau menyentuh area dari virtual button. Setiap event selesai dieksekusi, sistem akan menampilkan tombol objek lain yang berwarna merah secara acak untuk ditekan pemain.

\section{IMPLEMENTASI}

Pada implementasi, aplikasi dibangun menggunakan Bahasa pemograman C\#, perangkat pengembang Unity 3D dan Visual Studio 2012 serta Library Vuforia SDK. Aplikasi Piano Virtual menggunakan data set gambar penanda berupa file .jpg yang telah dikompres dan dikemas dalam bentuk file .unitypackage dari website Vuforia. Data set ini merepresentasikan penanda dalam bentuk data yang mana akan dimuat dalam kelas DatabaseLoadBehaviour sehingga sistem dapat membaca dan menggunakan data set tersebut untuk menampilkan objek 3 dimensi dalam aplikasi. Setelah penanda dimuat, sistem akan memulai untuk mengenali penanda yang berada pada area yang dilacak oleh kamera. Vuforia SDK dapat digunakan untuk gambar penanda yang lebih dari satu. Namun pada satu waktu, sistem hanya dapat mengenali satu jenis penanda. Proses pelacakan gambar marker diimplementasikan dalam kelas DefaultTrackableEventHandler. Dalam kelas ini, terdapat dua fungsi utama dalam pelacakan penanda, yaitu OnTrackingFound dan OnTrackingLost. Gambar penanda yang dipakai dapat dilihat pada Gambar 5. Kemudian susun dan konfigurasi objek 3 dimensi dan Virtual button pada gambar penanda. Gambar konfigurasi Virtual button pada marker dapa dilihat pada Gambar 6.

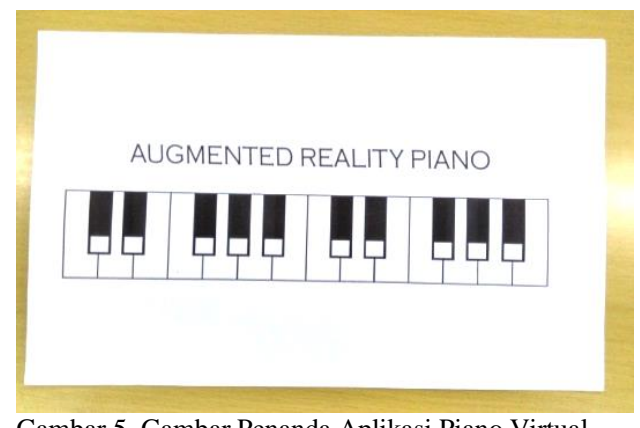

Gambar 5. Gambar Penanda Aplikasi Piano Virtual

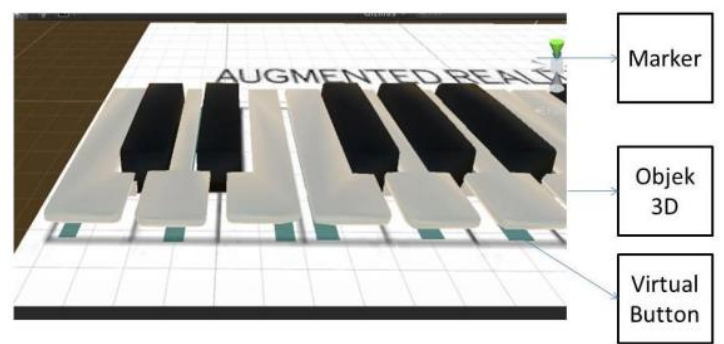

Gambar 6. Konfigurasi Virtual button pada Objek Piano

Pada proses permainan aplikasi ini, pengguna memilih tombol Start pada aplikasi, aplikasi memberikan dua pilihan jenis permainan yang diinginkan, yaitu Free Play dan Challenge. Free Play merupakan permainan piano virtual secara bebas, sedangkan Challenge merupakan permainan piano virtual yang memiliki tingkatan level untuk setiap lagunya. Berbeda dengan Free Play, pada jenis permainan Challenge terdapat penunjuk tuts yang harus ditekan, info not, Score, TimeCounter, dan GameOver sehingga pengguna dapat mengetahui skor dari tantangan yang diberikan. Halaman Free Play dapat dilihat pada Gambar 7, sedangkan halaman Challenge dapat dilihat pada Gambar 8.

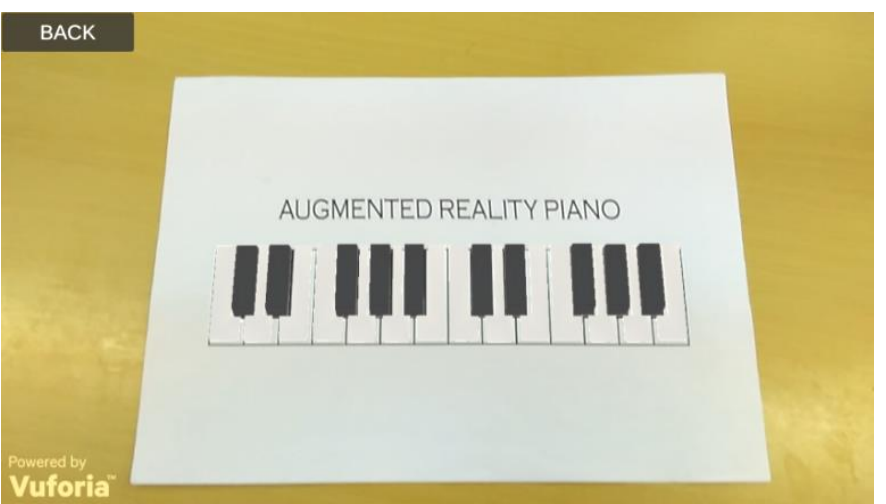

Gambar 7. Halaman Free Play

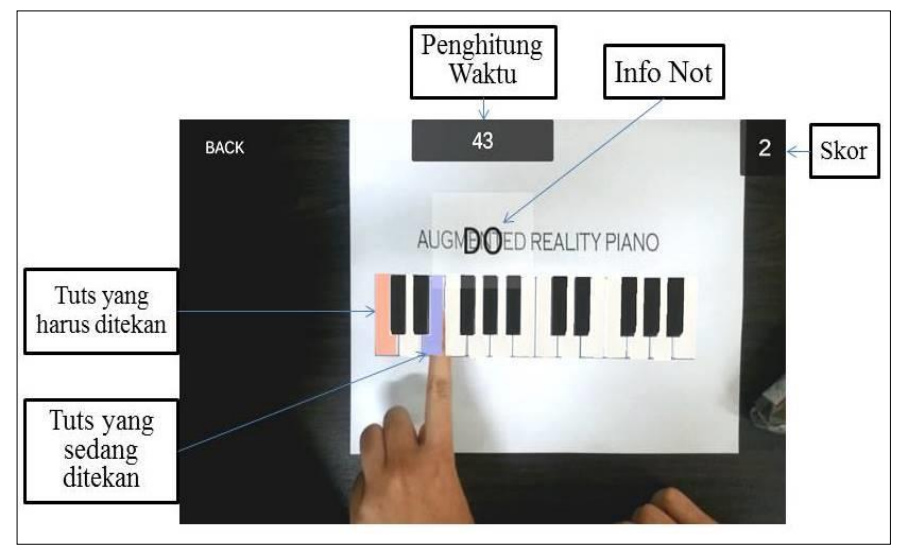

Gambar 8. Halaman Challenge

\section{PENGUJIAN TERHADAP PENGGUNA}

Setelah aplikasi selesai dibangun, maka perlu dilakukan pengujian dengan metode kuesioner untuk pengujian performance Augmented reality dari aplikasi piano, pengujian permainan dan tingkat kenyamanan aplikasi dengan melibatkan Mahasiswa Teknik Informatika FTIf ITS. Metode kuesioner yang digunakan adalah Likert-type scale dengan skala 1-6. pengisian kuesioner melibatkan enam responden yang sudah melakukan pengujian. Responden diminta untuk memainkan aplikasi ini, setelah itu responden diminta untuk mengisi kuesioner. Kuesioner tersebut berisi tiga parameter yang mana masing-masing parameter terdiri dari 3 pernyataan yang memiliki bobot penilaian sebagai berikut:

1. sangat tidak setuju $=1$,

2. tidak setuju $=2$,

3. kurang setuju $=3$,

4. cukup setuju $=4$,

5. setuju $=5$, 
6. sangat setuju $=6$.

Rangkuman hasil kuesioner dapat dilihat pada Tabel 1.

Tabel 1.

Hasil Kuesioner

\begin{tabular}{|c|c|c|}
\hline NO & PARAMETER & $\begin{array}{l}\text { NILAI } \\
\text { RATA } \\
\text { RATA }\end{array}$ \\
\hline \multicolumn{3}{|c|}{ TAMPILAN } \\
\hline 1. & $\begin{array}{l}\text { Aplikasi memiliki tampilan, desain dan warna yang } \\
\text { menarik }\end{array}$ & 4.3 \\
\hline 2. & Aplikasi memiliki tampilan yang mudah dipahami & 5 \\
\hline 3. & $\begin{array}{l}\text { Aplikasi memiliki tata letak tombol yang mudah } \\
\text { dikenali }\end{array}$ & 4.6 \\
\hline \multicolumn{3}{|c|}{ KENYAMANAN } \\
\hline 1. & $\begin{array}{l}\text { Aplikasi sudah nyaman digunakan (Dengan posisi } \\
\text { tangan memegang smartphone) }\end{array}$ & 3.15 \\
\hline 2. & $\begin{array}{l}\text { Aplikasi sudah nyaman digunakan (Tanpa memegang } \\
\text { smartphone, smartphone diletakkan di penyangga) }\end{array}$ & 4,8 \\
\hline 3. & Pengguna bingung saat memainkan aplikasi & 3 \\
\hline \multicolumn{3}{|c|}{ PERMAINAN } \\
\hline 1. & Aplikasi menyenangkan untuk dimainkan & 4.5 \\
\hline 2. & Permainan pada aplikasi mudah dipahami & 5 \\
\hline 3. & $\begin{array}{l}\text { Tampilan virtual dari piano yang muncul pada } \\
\text { smartphone sudah interaktif }\end{array}$ & 4.17 \\
\hline
\end{tabular}

Dari hasil kuesioner pada Tabel 1 didapatkan nilai rata-rata penilaian terhadap tampilan, kenyamanan dan permainan. Nilai yang sudah melebihi angka 4 yang berarti "Setuju.". Dari penilaian pada tampilan, pengguna cukup setuju aplikasi memiliki tampilan dan desain yang menarik, pengguna juga setuju bahwa aplikasi memiliki tampilan yang mudah dipahami dan pengguna cukup setuju bahwa tata letak tombol aplikasi mudah dikenali.

Dari penilaian pada kenyamanan, pengguna kurang setuju bahwa aplikasi telah nyaman digunakan jika sambil memegang smartphone, pengguna lebih setuju jika smartphone diletakkan di penyangga saat memainkan aplikasi. Pengguna juga kurang setuju bahwa pengguna bingung saat memainkan aplikasi.

Dari penilaian pada permainan, pengguna cukup setuju bahwa aplikasi menyenangkan untuk dimainkan. Pengguna juga setuju bahwa permainan aplikasi mudah dipahami. Pengguna cukup setuju bahwa tampilan piano virtual sudah interaktif.

\section{KESIMPULAN/RINGKASAN}

Aplikasi Piano Virtual yang dibangun menggunakan teknologi Augmented reality dan Vuforia SDK berhasil mendeteksi Virtual button fitur bawaan dari Library Vuforia SDK. Dari hasil pengujian, dapat disimpulkan bahwa aplikasi ini sudah menyediakan tampilan yang menarik dan mudah dipahami, permainan yang interaktif dan menyenangkan, serta aplikasi ini lebih nyaman dimainkan tanpa memegang smartphone dan diletakkan di penyangga.

\section{UCAPAN TERIMA KASIH}

Penulis R.F.F. mengucapkan terima kasih Jurusan Teknik Informatika Institut Teknologi Sepuluh Nopember, Direktorat Pendidikan Tinggi, Departemen Pendidikan dan Kebudayaan Republik Indonesia yang telah memfasilitasi penelitian ini.

\section{DAFTAR PUSTAKA}

[1] V. Chouvatut and W. Jindaluang, "Virtual Piano with Real-Time Interaction Using Automatic Marker Detection," in International Computer Science and Engineering Conference, 2013.

[2] Wikipedia, "Piano," [Online]. Available: https://en.wikipedia.org/wiki/Piano. [Accessed 18 Februari 2016].

[3] Wikipedia, "Musical Instrument," [Online]. Available: https://en.wikipedia.org/wiki/Musical_keyboard\#/media/File:Klaviatur3-en.svg. [Accessed Mei Juni].

[4] Wikipedia, "Augmented reality," [Online]. Available: https://en.wikipedia.org/wiki/Augmented_reality. [Accessed 18 Februari 2016].

[5] Wikipedia, "Vuforia Augmented reality SDK," [Online]. Available: https://en.wikipedia.org/wiki/Vuforia_Augmented_Reality_SDK. [Accessed 18 Februari 2016].

[6] Vuforia Developer, "Vuforia API Reference," [Online]. Available: https://developer.vuforia.com/library/sites/default/api/unity/annotated.ht ml. [Accessed Mei 2016].

[7] PTC Inc, "Frame Markers," [Online]. Available: https://developer.vuforia.com/library//articles/Training/Frame-MarkersGuide. [Accessed 18 Februari 2016].

[8] PTC Inc, "How To Implement Virtual buttons," [Online]. Available: https://developer.vuforia.com/library//articles/Solution/How-ToImplement-Virtual-Buttons. [Accessed 18 Februari 2016]. 